\title{
АВАНТЮРНО-ПРИГОДНИЦЬКИЙ СЮЖЕТ В УКРАЇНСЬКОМУ АВАНГАРДНОМУ РОМАНІ
}

У статті досліджуються особливості пригодницького сюжету у творах Майка Йогансена, О. Слісаренка, Гео Шкурупія, Юліана Шпола, Ю. Яновського. Складовими авантюрно-пригоднииького сюжету авангардного роману є пригоди, подорожі, несподівана розв'язка твору, загадки, інтриги, ефект достовірності, посилання на історичні події та образи персонажів.

Ключові слова: пригодницький сюжет, авантюра, інтрига, герой, ефект несподіванки, загадка.

В статье исследуются особенности приключенческого сюжета в произведениях Майка Йогансена, А. Слисаренко, Гео Шкурупия, Юлиана Шпола, Ю. Яновского. Составляющими авантюрно-приключенческого сюжета авангардного романа есть приключения, путешествия, неожиданная развязка произведения, загадки, интриги, эффект достоверности, ссылки на исторические события и образы персонажей.

Ключевые слова: приключенческий сюжет, авантюра, интрига, герой, эффект неожиданности, загадка.

In the article features adventure story in the works of Mike Johansen, O. Slisarenko, Geo Shkurupii, Julian Shpola, Y. Yanovsky. The components adventure story in vanguard novel is adventure, travel, unexpected denouement work puzzles, plot, the effect of authenticity, links to images of historical events and characters.

Keywords: adventure, adventure story, plot, character, effect of surprise, mystery. 
Письменники-авангардисти першої третини XX століття визначали авантюрність головним напрямком тогочасної прози й літератури загалом. Пригоди, подорожі, загадки, інтриги, посилання на історичні події, ефект достовірності є власне складовими пригодницької прози. Автори, вдаючись до інтригування читача, прагнули здивувати його, використовуючи для цього ефект несподіванки, таємниці, неймовірні відкриття, переслідування, загострення пристрастей тощо.

Авантюрно-пригодницький сюжет в українському авангардному романі кінця 20-х років XX століття розширює жанрові обрії, увиразнює та оновлює модерні прийоми зображення дійсності. Окрім пригодницького сюжету, новими були формальні прийоми, які письменники запроваджували у свої твори: іронія, пародіювання, гра, маскування. Пригодництво у контексті лівої прози закцентувало на формальних аспектах - композиції, деструкції форми. Художня проза цього періоду насичена авантюрно-пригодницькими сюжетами: Олекса Слісаренко «Чорний ангел», «Зламаний гвинт», Гео Шкурупій «Двері в день», «Жанна-батальйонерка», Юліан Шпол «Золоті лисенята», Майк Йогансен «Пригоди Мак-Лейстона, Гаррі Руперта та інших», «Подорож ученого доктора Леонардо та його майбутньої коханки Альчести у Слобожанську Швайцарію», Юрій Яновський «Майстер корабля» та інші.

Художні тексти пригодницького жанру грунтовно досліджені у літературознавчих працях Б. Бегака, А. Вуліса, В. Проппа (поетика жанру), Ю. Коваліва, А. Ткаченка (значення інтриги та загадки у пригодницькому творі), Д. Ліхачова та М. Бахтіна (проблеми авантюрного сюжету), А. Наркевич (пригодницька белетристика), О. Романенко, А. Ткаченка, С. Філоненко (відносять пригодницький жанр до масової літератури).

Експериментальна / авангардна проза 20-30-х років XX століття стала об’єктом дослідження сучасних літературознавців: Н. Бернадської, А. Білої, О. Боярчук, М. Васьківа, С. Жигун, О. Журенко, О. Капленко, Р. Мельниківа, Р. Мовчан, Л. Сеника, О. Ушкалова, О. Філатової, Я. Цимбал та інших, які вказують на жанрові дефініції, сюжетобудування, авторську інтенцію, ігрову 
поетику авангардного тексту. Однак, питання пригодництва, авантюрності у текстовому просторі авангардного роману потребують детальнішого дослідження. У статті ми спробуємо окреслити особливості авантюрнопригодницького сюжету, визначити його ознаки в авангардному тексті на прикладі романів Майка Йогансена, Олекси Слісаренка, Гео Шкурупія, Юліана Шпола, Юрія Яновського.

Формальне експериментаторство, авантюрні тенденції, пригодництво характерне для експериментальної прози кінця 1920-х років, про що зокрема писав Гео Шкурупій у романі «Двері в день»: «Я вважаю, щ⿻о романісти - изе машиністи, бухгалтери, робітники та селяни. Спитаєте чому? Скажете, щзо цุе парадокс? Нічого подібного. Придивіться, вони самі будують дивовижні та чудові романи. Вони якнайглибше занурилися у матеріал. Вони самі герої своӥх романів. Вони будують великий роман під назвою «майбутнє». Про щуо мріє один із нас? Про цุе, безперечно, можна написати велику книгу. Книгу, звичайно, напівсатиричну, бо ви, мабуть, знаєте, щзо про мрію сказав Пушкін. Кожен з нас щуе змалку мріє про різні пригоди. У той час, як ичі пригоди трапляються з нами щзодня, а ми їх i не помічаємо» [Шкурупій 1929:14]. Пригодницький сюжет сприяв зацікавленню та інтригував читача, адже автори могли переносити своїх героїв у різні кінці світу, щораз вигадуючи новий сюжет, не втрачаючи зв'язок пригод, бо «людина хоче подорожувати хоча б навколо своєї власної кватирі, а тим паче в далекі краї» [Йогансен 2009:392].

Пригодницько-авантюрний підхід продукує Гео Шкурупій у романі «Жанна-батальйонерка»: «гра в солдатики» захоплює дівчину і починається ii авантюрна місія - захоплена черговою «рекламною фальшивкою» уряду вона разом із іншими жінками їде на фронт «присоромити вояків», проте ця пригода закінчується розчаруванням. Специфіка структури роману Гео Шкурупія «Двері в день» базується на синтезі різножанрових елементів: авантюрного, пригодницького роману та репортажу. Така структура детермінувала відтворення автором мистецьких реалій. Пригоди, переживання Теодора Андрійовича Гая подані автором фрагментарно. Письменник вдається до 
прийому «потоку свідомості», де кожна наступна думка героя пов’язана 3 попередньою тільки асоціативно. Автор вважає, що фантазія, уява, вимисел мають більше значення, ніж реальність, саме тому, використовуючи прийом «очуднення», одягає маску на свого героя: маска нудьги, маска фантазування, маска фіктивної смерті, маска мрійника та закоханого. Для того, щоб порвати 3 ненависним йому життям, непманським оточенням, дружиною, Теодор Гай вдається до авантюри - інсценує свою смерть і назавжди зникає 3 міста (насправді це є лише сном героя). Така інтрига автора сприяла не тільки майстерності конструювання сюжету, але й була «ошуканством читача» (Т. Белімова), розігруванням читацьких сподівань.

«Золоті лисенята» Юліана Шпола, на думку Р. Мельниківа, «ціікавий експеримент, поєднання гостросюжетного пригодницького роману 3 авангардними прийомами та неоромантичним натхненним пафосом й інтонаціями „вітаӥзму”» [Мельників 2007], в якому синтезовано елементи політичного, авантюрного, кримінального та любовного романів. Для твору характерна атмосфера таємничості та загадковості, проте розгадка у творі виглядає дещо штучною: «Мене таки зрадив той дідок, щ̧о їхав тоді в потязі разом зо мною. Друкарню провалив сам Мем, щуо в нього один із помічників був провокатор. А замах не вигорів тільки через те, щуо один із підручних Мандибули підсунув йому в револьвер порожні патрони (він теж був провокатор, у цее саме він загубив тоді у схованц̧і на ц̧винтарі свою хустку $з$ літерою «M») [Шпол 1929:266]. Автор, зберігаючи сюжетну напругу, тримає інтригу, проте подає розшифровку не аргументовано. Пригодницький роман акцентує на мотиві подорожі, дороги, саме тому «численні пригоди та долання усіляких перипетій героями твору створюють постійні сюжетні афекти, щуо ставлять їх у незвичайні моральні випробування, коли потрібно вибирати між добром і злом, правдою $і$ кривдою, хоч інколи цุі ситуації приводять їх на слизьку дорогу хиб і гріха» [Цуркан 2006:173].

Однією з прикметних ознак пригодницького сюжету є любовна історія, «любовний трикутник». Взаємини персонажів у романі Юліана Шпола 
виписані у дусі любовного роману із певними інтригами i загадками. Тема кохання у творі передана через заплутані любовні взаємини персонажів, і цю загадку автор розкриває тільки в кінці твору: «Мавка любила Мема, але жила з Озоном, а Кірка любила Озона, але жила з товаришем Мандибулою» [Шпол 1929:266]. Та й справжнє ім’я Озона дізнаємося тільки в кінці роману, який виявляється товаришем Петляєм й оповідачем, а дівчина на возі - це згодом розстріляна Оксана. Ця таємниця вмотивована у дусі революційних перипетій, де кожен представник політичного руху мав для конспірації певний псевдонім. Подорож оповідача насичена романтичними та пригодницькими елементами (під час короткої поїздки на нього чекають несподіванки: захоплення дівчиною, що переростає у закоханість, арешт, полон і втеча із-під розстрілу); підготовка та здійснення теракту - це від детективного роману. Концепт загадки, яку читач розгадує поступово, зближує роман 3 пригодницьким та детективним сюжетами.

«Чорний ангел» Олекси Слісаренка - пригодницька історія часів громадянської війни про більшовика, вченого-мрійника Артема Гайдученка, який працює над створенням супер-добрива, що повинно стати новим винаходом у сільському господарстві. Артем Гайдученко живе у своєму, відокремленому, відірваному від буденності світі, створюючи так званий «безлюдний острів», що $є$ складовою традиційного пригодницького сюжету. Кожен із персонажів є авантюрником, має свою таємницю, приховану історію, одержимий утопічною ідеєю, яку прагне реалізувати у власному ідеальному «проекті»: Артем Гайдученко - винахід термініду (унікальної речовини, яка стане невичерпним джерелом енергіi), Петро Гайдученко - боротьба з ворогами України та використання винаходу Артема на користь людства, Андрій Чмир реалізація соціалістичного устрою, Тома Карлюга - усамітнення для пошуку себе, істини. Артем, Петро та Тома гинуть на шляху до здійснення мети. На думку Ю. Лаврісюк, саме «акумуляціія таємницьь формує грунт для пригод, за допомогою яких вони мають бути розкриті» [Лаврісюк 2008:14]. Секрети персонажів автор розкриває психологічно мотивуючи їх вчинки: «Майже сім 
років блукань по всіх усюдах без можливості заглибитись у свою праџю позбавили були його рівноваги й загострили нервову систему до того ступеня, коли найменша дрібниия псує настрій на иџілі тижні й кидає в каламутні води прострачіï. Тепер, ідучи мовчазним лісом, Гайдученко мріяв про той час, коли ніхто йому вже не заважатиме працювати і він провадитиме далі свої досліди в тиші всіма покинутої садиби десь у глибині цього мовчазного лісу. ... Якихсь два-три роки і справа, яку задумав Гайдученко ще в школі, стане справою иілої краӥни, а можливо, й иілого світу...» [Слісаренко 1990:402]. Текстова тканина твору насичена не тільки авантюрними, але й містичними елементами, змалюванням буремних революційних та постреволюційних подій, створення комун, і це дало підстави Олександру Білецькому визначити роман як, власне, перший добротний авантюрно-революційний роман в українській літературі [Белецкий 1930:7-8].

Майкл Йогансен у назви своїх творів виносить елемент авантюрності, провокуючи реципієнта на інтелектуально-емоційні переживання: «Пригоди Мак-Лейстона, Гаррі Руперта та інших», «Подорож ученого доктора Леонардо та його майбутньої коханки Альчести у Слобожанську Швайцарію». «Подорож вченого доктора Леонардо...» $є$ авангардним текстом, в якому діє настанова на епатажування читача, на руйнування умовності зображуваного. Авантюрнопригодницький сюжет роману наповнений поетичними ремінісценціями, ліричними відступами. Елементи белетристичного, наукового, публіцистичного плану синтезовані в певну художню цілісність. Динамічність сюжету, випадковий збіг, атмосфера дива, ефект несподіванки наповнюють текст «Подорожі...», що виражається через перевтілення (метаформозу) головного героя: «Він був уже не Дон Хосе Перейра, інтелігент і тиранобореиь, а Данько Харитонович Перерва, степовик $i$ член степового райвиконкому» [Йогансен 2009:404]. Власне для пригодницького роману, вважає А. Вуліс, «дива виявляються запланованими заходами, $і$ кожна метаморфоза виглядає подією настільки ж обов'язковою, як моральне перевтілення злочиния $у$ поганому детективі» [Вулис 1986:63]. 
Пригодницький сюжет репрезентований у романі Ю. Яновського «Майстер корабля» через розповіді про пригоди моряка Богдана. Пригодницька лінія супроводжується цікавим екзотичним колоритом, описами країн (острів Ява, Пао, Генуя, Філіппіни, Далекий Схід), в яких довелося побувати хазяїну трамбака: «Плавав я на піввантажному пароплаві юнгою.. <..> Війна нас застукала в японських водах. Ми йшли на південь, повертаючися 3 Владивостока. Стояла страшна спека. <..> Потім почався тайфун. <..> Кілька днів носило нас, поливаючи водою, підкидаючи вгору, шпурляючи в безодні... <..> I перша земля, яку ми побачили, була Філіппінських островів» [Яновський 1983:79]. Саме на цих островах розташоване місто Маніла, яке вразило Богдана: «Я його (місто - С. Ж.) побачив на другий день увечері. Не можу не згадати, як заходить у тих краях сонце. Наче зібрано всі фарби в світі й вилито в синє-пресинє море. На небі неймовірні пейзажі, зелені острови, червоні пожежі, пурпурові прапори. Це біснування кольорів було б штучним на наших бідних берегах, та там, серед загального багатства декорацій, воно навіть не приголомшує уяви» [Яновський 1983:79]. Для зацікавлення читача та ефекту достовірності письменник у пригодницький сюжет вводить реальні географічні назви, імена, дати.

Пригодницький сюжет сприяє увиразненню жанрової матриці твору, образів, адже герої роману є пристрасними натурами, які прагнуть до нових висот творчої праці, вносять дух неспокою, оптимізму, пориваються, як i митець твору, до нових творчих звершень. Автор поєднує у творі проблеми мистецтва, нації з романтикою пригод. Л. Кавун зауважує, що оспівана в романі «Майстер корабля» ідея творчості, духовного зростання України ніби дисонує 3 тим світовідчуванням, яке переймає художню прозу 20-х років XX століття як цілість, 3 домінантою трагічного хаосу й абсурду людського існування, тривоги за долю нації: «Роман став своєрідною сходинкою в усвідомленні украӥнською людиною себе як частини певної нації» [Кавун 2009:368]. 
Пригодницькі романи захоплюють не тільки стрімкими, непередбачуваними, таємничими історіями, але й характерами персонажів, які психологічно виписані. Герої таких творів фізично міцні та духовно багаті, часто позитивні, навіть ідеалізовані, виховні «відповідно до кращчих потреб суспільства», здатні «пов’язувати своє життя з майбутнім своєї краӥни, опинятися в гострих, завжди ціікавих, хвилюючих $і$ правдивих колізіях, конфліктах» [Кердівар 2008:106]. Крім того, це не тільки шукачі пригод та стрімких почуттів, авантюристи, спритні, щасливі герої, а й громадяни країни, які «у своӥх діях виходять з інтересів держави, народу»[Кердівар 2008:105]. Саме таких персонажів змальовує Юрій Яновський у «Майстрі корабля», адже Сев, То-Ма-Кi, Тайях, Директор, Богдан є тими героями, хто йде вперед, не схиляється перед труднощами, віддані своїй меті. Молодший син То-Ма-Кі називає Богдана неймовірним оптимістом: «За такими людьми мимоволі йдуть. 3 ними дуже легко жити. Вони сприймають життя в ияілому, в нещзасті знаходять радість, у болі - чують натхнення. В страхові - знають сміх. Їх натовп висуває наперед. Вони - співаки, щзо знають силу пісень $і$ співають їх $y$ такт ході» [Яновський 1983:143].

Типологія жанру пригодницького роману вимагає від письменника збереження сюжетної напруги та інтриги до кінця. Задум письменника реалізований у композиції твору, сюжеті, ідеї, зображально-виражальних засобах та авторській інтенції. У романі «Двері в день» Гео Шкурупій екстраполює авторську аргументацію сутності пригодницької історії, поданої у текстах: «Багато романтичних людей дуже жалкують, щ̧о всі таємниц̧і викриваються та пояснюються досить просто, щуо немає в наш вік загадкових історій, щ⿻ їх так часто можна прочитати в книжках романістів. Що ж поробим? Звичайно, щзоб задовольнити аматорів таємничих історій, можна таку історію винайти, але при денному світлі всі таємниці стають реальними» [Шкурупій 1929:46-47].

Атрибутика авантюрно-пригодницької розповіді оприявлена у структурі авангардної прози. Пригодницький сюжет сприяв експериментуванню 3 
героями, композицією роману й став одним із найпоширеніших в українському авангардному / експериментальному / лівому романі.

\section{БІБЛІОГРАФІЯ}

Белецкий 1930 - Белецкий А. И. О. Слисаренко / А. И. Белецкий // Слисаренко О. Чѐрный ангел : [роман]. - М. -Л. : ГН3, 1930. - С. 3-9.

Вулис 1986 - Вулис А. 3. В мире приключений. Поэтика жанра / А. 3. Вулис. - М. : Советский писатель, 1986. - 384 с.

Йогансен 2009 - Йогансен М. Вибрані твори / Майк Йогансен ; [упоряд., передм. Р. Мельниківа]. - 2-ге вид., доповнене. - К. : Смолоскип, 2009. - 768 с.

Кавун 2009 - Кавун Л. Художня модель ідеального світоустрою в романі Юрія Яновського «Майстер корабля» / Лідія Кавун // Актуальні проблеми слов’янської філології. Серія : Лінгвістика і літературознавство : міжвуз. зб. наук. ст. / [відп. ред. В. А. Зарва]. - Бердянськ : БДПУ, 2009. - Вип. ХХІІ. C. $367-375$.

Кердівар 2008 - Кердівар Н. І. Утвердження позитивного начала в образній структурі прози М. Трублаїні / Н. І. Кердівар // Вісник Запорізького національного університету. - Запоріжжя, 2008. - № 2. - Серія : Філологічні науки. - С. 104-108.

Лаврісюк 2008 - Лаврісюк Ю. А. Дискурс неореалістичної прози Олекси Слісаренко (жанрово-стильові модифікації) : автореф. дис. на здобуття наук. ступеня канд. філол. наук : спец. 10.01.01 - українська література / Ю. А. Лаврісюк. - Київ, 2008. - 21 с.

Мельників 2007 - Мельників Р. Капелюш і таємниці Юліяна Шпола [Електронний ресурс] / Ростислав Мельників // Народне слово. - 2007. 13 вересня. - Режим доступу : www.slovo-unp.com.

Слісаренко 1990 - Слісаренко О. Чорний Ангел : вірші, новели, повісті, роман / Олекса Слісаренко ; [упоряд., передм. М. К. Наєнка, ред. Н. Д. Олександренко]. - К. : Дніпро, 1990. - 557 с.

Цуркан 2006 - Цуркан I. M. Типологічні аспекти історикопригодницького роману / I. М. Цуркан // Філологічні науки : наукові праці. 2006. - Т. 59. Вип. 46. - С. 169-175. 
Шкурупій 1929 - Шкурупій Г. Двері в день : [роман] / Гео Шкурупій. Х. : Пролетарій, 1929. - 232 с.

Шпол 1929 - Шпол Ю. Золоті лисенята / Юліан Шпол. - Харків : Книгоспілка, 1929. - 268 с.

Яновський 1983 - Яновський Ю. І. Твори : в 5-ти т. / Ю. І. Яновський. К. : Дніпро, 1983. - Т. 2 : романи / [упоряд., прим. К. П. Волинського, М. Острика; післям. М. Пархоменка]. - 1983. - 424 с. 